\title{
Masalah-Masalah terkait Pengobatan Diabetes Melitus Tipe 2: Sebuah Studi Kualitatif
}

\author{
Retno Wahyuningrum ${ }^{1}$, Djoko Wahyono ${ }^{2}$, Mustofa ${ }^{3}$, Yayi S. Prabandari ${ }^{4}$ \\ ${ }^{1}$ Program Studi Farmasi, Fakultas Sains dan Teknologi, Universitas Sembilanbelas November Kolaka, \\ Kolaka, Indonesia, ${ }^{2}$ Departemen Farmakologi dan Farmasi Klinik, Fakultas Farmasi, Universitas \\ Gadjah Mada, Yogyakarta, Indonesia, ${ }^{3}$ Departemen Farmakologi dan Terapi, Fakultas Kedokteran \\ Kesehatan Masyarakat dan Keperawatan, Universitas Gadjah Mada, Yogyakarta, Indonesia, \\ ${ }^{4}$ Departemen Perilaku Kesehatan Lingkungan dan Kedokteran Sosial, Fakultas Kedokteran Kesehatan \\ Masyarakat dan Keperawatan, Universitas Gadjah Mada, Yogyakarta, Indonesia
}

\begin{abstract}
Abstrak
Pengelolaan diabetes melitus tipe 2 (DMT2) yang kompleks memicu masalah-masalah yang menyebabkan sasaran terapi tidak tercapai. Tujuan penelitian ini adalah untuk mengidentifikasi masalah-masalah yang dialami pasien DMT2 dalam pengobatan. Pendekatan kualitatif digunakan dalam desain penelitian ini. Pengumpulan data melalui wawancara semiterstruktur, bertatap muka. Rekrutmen partisipan dilakukan di poliklinik penyakit dalam rumah sakit di Yogyakarta (RSUD Sleman, RS Bethesda, dan RSUD Wates) pada bulan November 2015-Mei 2016. Kombinasi pertanyaan terbuka dan tertutup diterapkan untuk memperoleh jawaban dari partisipan. Pertanyaan-pertanyaan wawancara terkait dengan pemahaman tentang penyakit dan obat, aktivitas perawatan diri diabetes, komunikasi dengan tenaga kesehatan, dukungan sosial, dan kondisi psikologis. Setiap sesi wawancara direkam audio, ditranskrip verbatim, dan dianalisis menggunakan matriks. Partisipan juga diperiksa kadar HbA1c untuk mengetahui baikburuknya kontrol glikemik. Dua puluh tiga partisipan memenuhi sesi wawancara, berusia antara 3572 tahun dan didominasi perempuan $(\mathrm{n}=12)$. Kadar HbA1c rata-rata 7,9 $\pm 2,0 \%$. Hasil analisis data teridentifikasi masalah pasien DMT2 dikategorikan menjadi masalah terkait faktor demografi, sosial, gaya hidup, hubungan dengan tenaga kesehatan, pemahaman mengenai penyakit, efek penyakit, pengendalian penyakit, komorbiditas, pengetahuan tentang pengobatan, dan asupan obat. Pemberian edukasi dan konseling kefarmasian sebaiknya tidak hanya berorientasi pada terapi farmakologi saja, namun juga memberikan motivasi pada pasien untuk mengubah perilaku, serta mempertimbangkan faktor psikologis dalam pengelolaan DMT2.
\end{abstract}

Kata kunci: Diabetes melitus, edukasi, konseling, masalah terkait pengobatan, wawancara

\section{Medication-related Problems in Patients with Type 2 Diabetes Mellitus: A Qualitative Study}

\begin{abstract}
The complexity of type 2 diabetes mellitus (T2DM) management offers plenty of challenges to patients. Poor glycaemic control, the presence of complications and comorbidities, and non-adherence furnish the challenges in arranging glycaemic target. This study was performed to explore the medicationrelated problems experienced by T2DM patients during treatment. Qualitative research was conducted through face-to-face semi-structured interviews. The combination of open- and closed-ended questions was formulated focusing on domains including illness- and medicine-related knowledge, diabetes self-care activities, patient-healthcare professional communication, social support, and psychological conditions. Interview sessions were audio-recorded, transcribed verbatim, and analyzed into matrix. Glycated hemoglobin (HbA1c) were measured to assess glycaemic control. Twenty-three T2DM outpatients from three general hospitals in Yogyakarta (Sleman District Hospital, Bethesda Hospital, and Wates District Hospital) were recruited and completed the protocol. The participants were 35-72 years old, was dominated by female $(\mathrm{n}=12)$, and had a mean $\mathrm{HbA} 1 \mathrm{c}$ level $7.9 \pm 2.0 \%$. Perceived factors leading medication therapy problems were of three types and related to: patient-, clinical condition-, and medicine-related factors. Patient-related factors were related to sociodemographic, lifestyle, and relationship with healthcare provider. Clinical condition-related factors included knowledge about illness, effects of illness, control over symptoms, comorbidities. Medicine-related factors associated with lack of knowledge about medicines and medicine use. This study concluded that behavior change and psychological well-being should be noticed when leading diabetes education and counseling.
\end{abstract}

Keywords: Counseling, diabetes mellitus, education, interview, medication therapy problems

Korespondensi: Dr. apt. Retno Wahyuningrum, M.Sc., Program Studi Farmasi, Fakultas Sains dan Teknologi, Universitas Sembilanbelas November Kolaka, Kolaka, Sulawesi Tenggara 93517, Indonesia, email: retno2408@yahoo.co.id

Naskah diterima: 31 Juli 2019, Diterima untuk diterbitkan: 28 Februari 2020, Diterbitkan: 31 Maret 2020 


\section{Pendahuluan}

Penyakit diabetes melitus (DM) termasuk dalam sepuluh penyakit tidak menular yang menduduki peringkat teratas kasus terbanyak dan merupakan penyakit dengan beban pembiayaan terbesar. ${ }^{1}$ DM tipe 2 (DMT2) merupakan bentuk paling umum dari diabetes. Terapi pengobatan DMT2 terdiri dari lima komponen utama yaitu pengaturan makan, olahraga, pemantauan status metabolik, terapi farmakologi, dan edukasi.,3 Sebagian besar pasien DMT2 mengalami kesulitan dalam pengelolaan diri terkait aktivitas fisik, makan sehat, penggunaan obat, pemantauan glukosa darah, serta pengelolaan stres. ${ }^{4-6}$ Menurut perspektif dokter, sebagian besar pasien yang mendapatkan terapi insulin gagal mencapai sasaran terapi disebabkan faktor pola hidup, ketidakpatuhan, dan kekhawatiran tentang biaya pengobatan yang tidak ditanggung oleh asuransi (out-of-pocket costs). ${ }^{7}$

Beberapa contoh masalah terkait dengan obat yang paling banyak ditemukan pada pasien DMT2 adalah penggunaan obat tanpa indikasi (proton pump inhibitor atau $\mathrm{H}_{2}$ blocker diresepkan saat tidak ada indikasi gastritis atau ulkus), ${ }^{8}$ penggunaan obat yang tidak tepat oleh pasien, pemilihan obat yang tidak tepat terkait dengan indikasi (pasien dengan kadar $\mathrm{HbA} 1 \mathrm{c}<7,5 \%$ diresepkan insulin, bukan antidiabetes oral), kontraindikasi dengan kondisi fisiologis (pasien usia lanjut diresepkan metformin, padahal obat tersebut tidak direkomendasikan untuk orang yang berusia di atas 70 tahun), kepatuhan (obat tidak diminum), interaksi obat dengan obat, masalah dosis obat (terlalu rendah dan terlalu tinggi), serta efek samping obat. ${ }^{9-11}$ Masalah lainnya adalah gaya hidup yang tidak tepat, meliputi konsumsi rokok, kegemukan (indeks massa tubuh $>25 \mathrm{~kg} / \mathrm{m}^{2}$ ), kurang olahraga, kurang kunjungan rutin ke dokter mata atau ahli penyakit kaki (podiatris), keterbatasan pengetahuan mengenai penyakit serta tidak menyadari tipe DM yang diidap, pengaruh negatif dari makanan (alkohol atau coklat) terhadap kadar glukosa darah, pengaruh obat pada penyakit dan/atau komplikasi, penyebab hipoglikemia, cara mengendalikan glukosa darah dengan makanan, dan tidak mengetahui efek merugikan dari obat. ${ }^{9,12}$ Selain masalah tersebut, faktor-faktor psikososial seperti stres, ansietas, kurangnya dukungan dari anggota keluarga, serta perilaku, turut mempersulit tercapainya kontrol glikemik yang optimal. ${ }^{4}$

Sifat dari penyakit DM yaitu tidak dapat disembuhkan dan seringkali menimbulkan komplikasi di banyak bagian tubuh, serta meningkatkan risiko kematian dini. ${ }^{13}$ Kurang lebih 800 ribu pasien DM telah mengalami amputasi kaki, kebutaan, kerusakan saraf, gagal ginjal, strok, dan serangan jantung. ${ }^{1}$ Prevalensi retinopati diabetik di Indonesia adalah $43,1 \%$ terutama pada pasien DM di daerah pedesaan, dengan usia 60-70 tahun, dengan durasi DM lebih dari 20 tahun. ${ }^{14} \mathrm{Hal}$ itu dipicu kurangnya kesadaran masyarakat mengontrol glukosa darah, serta mengubah pola hidup meski kadar glukosa darahnya di atas normal. ${ }^{15}$ Penelitian ini dilakukan untuk mengeksplorasi permasalahan yang dijumpai dalam pengobatan pasien DMT, dan hasil penelitian ini digunakan sebagai dasar pengembangan modul konseling yang dapat diterapkan untuk meningkatkan pengetahuan tentang DM, perilaku, kepatuhan pengobatan, dan luaran klinik pasien DMT2.

\section{Metode}

Desain

Studi kualitatif dilakukan untuk menggali pemahaman, persepsi, sikap, tindakan dan pengalaman terkait penyakit dan pengobatan, serta masalah-masalah yang terkait dengan psikologis dan kehidupan sosial yang dapat memengaruhi penyakit dan pengobatan. ${ }^{15,16}$ Pengumpulan data dilakukan dengan teknik wawancara semiterstruktur dengan cara tatap 


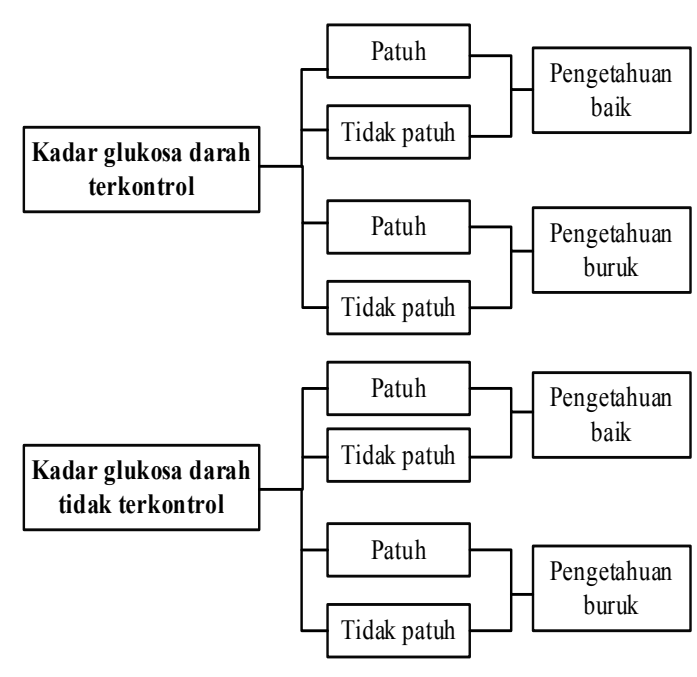

Gambar 1 Variasi Informan Penelitian

muka langsung dengan informan. Seluruh percakapan direkam dengan menggunakan alat perekam suara atas persetujuan partisipan. Respon nonverbal (seperti tersenyum, tertawa, terlihat sedih, merasa marah, ragu-ragu) yang muncul selama wawancara dicatat apabila perlu. Penulisan naskah publikasi penelitian ini mengacu pada Standards for Reporting Qualitative Research (SRQR). ${ }^{17}$

Tempat dan subjek penelitian

Rekrutmen partisipan dilakukan di rumah sakit umum yang terletak di Daerah Istimewa Yogyakarta (DIY) yang merupakan provinsi dengan prevalensi penderita DM tertinggi di Indonesia. ${ }^{18}$ Rumah sakit pertama yang dipilih yaitu RSUD Sleman yang merupakan rumah sakit milik pemerintah daerah kabupaten yang berpenduduk terbanyak se-provinsi. ${ }^{19}$ Kedua, RSUD Wates yang mewakili daerah rural. Ketiga, RS Bethesda yang terletak di kawasan strategis pusat Kota Yogyakarta. Rumah sakit-rumah sakit tersebut merupakan fasilitas layanan kesehatan sekunder tipe B, memiliki pelayanan spesialis penyakit dalam, dan terakreditasi paripurna. Pengambilan data dilakukan pada tahun 2015-2016.

Partisipan dipilih secara purposive dengan teknik sampling variasi maksimum (Gambar 1) untuk memperoleh keragaman informan. ${ }^{20}$
Keterangan:

- Patuh-tidaknya pasien dalam menggunakan obat diidentifikasi dari informasi terkait dengan frekuensi tidak minum obat atau tidak suntik insulin dalam satu bulan terakhir.

- Baik-buruknya pengetahuan pasien tentang obat diidentifikasi dari bisatidaknya pasien menyebutkan dengan benar nama atau identitas obat yang sedang digunakan, fungsi obat, efek yang diharapkan dan tidak diharapkan, cara penggunaan, tempat penyimpanan, pengalaman menggunakan obat/obat tradisional.

- Baik-buruknya pengetahuan pasien tentang penyakit dipastikan dari penjelasan pasien tentang penyebab dan gejala penyakit, sifat penyakit, kadar glukosa darah normal, komplikasi DM, penyakit penyerta, pengelolaan penyakit termasuk kebiasaan olahraga, diet, pemeriksaan kadar glukosa darah, pemeriksaan kaki sendiri, kondisi pengelihatan.

Kriteria inklusi partisipan adalah pasien rawat jalan yang didiagnosis dokter DMT2 (tertulis dalam rekam medik) yang berkunjung di poliklinik penyakit dalam; berusia 18 tahun atau lebih; mendapatkan terapi antidiabetes oral (ADO) saja, insulin saja, atau kombinasi keduanya; bersedia untuk mengikuti penelitian dengan menandatangani lembar persetujuan. Pasien-pasien yang mengalami gangguan pada fungsi pendengaran, tidak mampu diajak berkomunikasi, pikun, dan tidak memenuhi sesi wawancara dieksklusi.

\section{Instrumen penelitian}

Pedoman wawancara semiterstruktur digunakan untuk mengumpulkan data (Tabel 1). Pengembangan panduan wawancara ini mulanya dilakukan dengan proses pencarian referensi secara komprehensif dari pustaka maupun penelitian-penelitian terdahulu. ${ }^{9,21-30}$ Partisipan tidak mengalami kesulitan ketika menjawab pertanyaan dalam sesi wawancara karena menggunakan bahasa yang sederhana dan mudah dimengerti tanpa menggunakan istilah-istilah medis. Pertanyaan terbuka dan tertutup digunakan untuk memperoleh jawaban dari partisipan. Probing dilakukan untuk memperoleh keterangan secara lebih mendalam dari respon partisipan terhadap suatu pertanyaan. Pertanyaan wawancara 
Tabel 1 Pedoman Wawancara

\begin{tabular}{|c|c|}
\hline Tema & Contoh Pertanyaan dan Probing \\
\hline $\begin{array}{l}\text { Penyebab dan sifat } \\
\text { penyakit }\end{array}$ & $\begin{array}{l}\text { Menurut bapak/ibu apa sebenarnya sakit gula atau diabetes itu? } \\
\text { Probing: } \\
\text { 1. Mungkin dapat dijelaskan lebih lanjut, sakit gula itu sakit yang parah atau } \\
\quad \text { hanya sakit yang ringan saja? } \\
\text { 2. Mengapa bapak/ibu menderita sakit tersebut? } \\
\text { 3. Apakah sakit gula dapat disembuhkan? }\end{array}$ \\
\hline $\begin{array}{l}\text { Penyakit penyerta dan } \\
\text { komplikasi diabetes } \\
\text { melitus }\end{array}$ & $\begin{array}{l}\text { Apa yang bapak/ibu lakukan selain minum obat untuk mengurangi keparahan sakit } \\
\text { gula? } \\
\text { Menurut bapak/ibu apa yang akan terjadi bila sakit gulanya tidak diobati? } \\
\text { Probing: } \\
\text { 1. Menurut bapak/ibu jika sakit gula tidak terkontrol apakah bisa kemungkinan } \\
\text { menjadi sakit darah tinggi atau jantung atau ginjal? } \\
\text { 2. Setelah didiagnosis mengalami sakit gula, apakah bapak/ibu pernah mengalami } \\
\text { sakit lain? Menurut bapak/ibu apakah sakit tersebut ada hubungannya dengan } \\
\text { sakit gula? }\end{array}$ \\
\hline Perilaku perawatan diri & $\begin{array}{l}\text { Apakah menurut bapak/ibu olahraga bisa meringankan sakit bapak/ibu? } \\
\text { Probing: Apakah bapak/ibu sering berolahraga? Olahraga apa yang bapak/ibu } \\
\text { jalankan? }\end{array}$ \\
\hline \multirow[t]{3}{*}{ Penggunaan obat } & $\begin{array}{l}\text { Apa saja yang bapak/ibu harapkan setelah mengonsumsi obat-obat gula? } \\
\text { Probing: } \\
\text { 1. Apakah dokter/apoteker menjelaskan tentang fungsi obat-obat tersebut? } \\
\text { 2. Bagaimana bapak/ibu menggunakan obat tersebut? (dosis, frekuensi, waktu } \\
\text { minum obat/suntik insulin, cara minum obat/suntik insulin) }\end{array}$ \\
\hline & $\begin{array}{l}\text { Apakah bapak/ibu pernah mengalami efek yang tidak diinginkan setelah minum } \\
\text { obat/suntuk insulin? } \\
\text { Probing: } \\
\text { 1. Bagaimana bapak/ibu menangani efek tersebut? } \\
\text { 2. Apakah bapak/ibu merasa khawatir obat-obat tersebut menyebabkan penyakit/ } \\
\text { masalah kesehatan lain? }\end{array}$ \\
\hline & $\begin{array}{l}\text { Apakah bapak/ibu menggunakan obat lain selain yang diberikan rumah sakit? Obat } \\
\text { tradisional/alternatif mungkin? } \\
\text { Probing: } \\
\text { 1. Dari manakah bapak/ibu mendapatkan obat tradisional/jamu/alternatif tersebut? } \\
\text { 2. Apakah ada pengaruh yang lebih baik jika menggunakan obat tersebut daripada } \\
\quad \text { obat yang diresepkan dokter? }\end{array}$ \\
\hline $\begin{array}{l}\text { Komunikasi dengan } \\
\text { tenaga kesehatan }\end{array}$ & $\begin{array}{l}\text { Pernahkah bapak/ibu berkonsultasi dengan dokter atau tenaga kesehatan yang lain } \\
\text { tentang sakit gula? } \\
\text { Probing: Apa yang dokter anjurkan untuk mengurangi sakit bapak/ibu? Bagaimana } \\
\text { hasil yang dirasakan setelah mengikuti anjuran dokter? }\end{array}$ \\
\hline Peran keluarga terdekat & $\begin{array}{l}\text { Siapa di antara anggota keluarga atau teman yang sering mengingatkan minum } \\
\text { obat/suntik insulin atau melakukan hal lain yang berkaitan dengan kesembuhan } \\
\text { sakit bapak/ibu? } \\
\text { Probing: Secara umum, seberapa puaskah bapak/ibu dengan dukungan yang } \\
\text { diberikan teman/keluarga terkait dengan kesembuhan penyakit? }\end{array}$ \\
\hline $\begin{array}{l}\text { Pengelolaan stres } \\
\text { psikologis }\end{array}$ & $\begin{array}{l}\text { Bagaimana pendapat bapak/ibu tentang pengaruh stres terhadap kondisi kesehatan? } \\
\text { Probing: Menurut bapak/ibu mana yang lebih dominan meningkatkan gula darah: } \\
\text { makanan, kurang olahraga, atau pikiran? Bagaimana cara bapak/ibu mengendalikan } \\
\text { stres? }\end{array}$ \\
\hline
\end{tabular}


terkait dengan pengetahuan tentang penyakit, perilaku perawatan diri dan penggunaan obat diabetes, komunikasi dengan tenaga kesehatan, dukungan sosial, dan pengelolaan stres psikologis. Probing digunakan sebagai cara untuk mengklarifikasi jawaban partisipan atau memperoleh keterangan tambahan yang lebih terperinci dan spesifik.

\section{Proses wawancara}

Proses wawancara dilakukan dalam Bahasa Indonesia. Jika partisipan memiliki kendala pada bahasa, maka tanya-jawab dilakukan dalam Bahasa Jawa, yang merupakan bahasa lokal masyarakat Yogyakarta. Pengumpulan data dilakukan oleh peneliti utama yaitu penulis pertama yang merupakan karyasiswa Program Studi S3 Ilmu Farmasi Fakultas Farmasi Universitas Gadjah Mada, berjenis kelamin perempuan, dapat berkomunikasi dalam Bahasa Jawa dan Bahasa Indonesia, serta berlatar belakang pendidikan Sarjana Farmasi, Apoteker, Magister Manajemen Farmasi. Durasi wawancara kurang lebih selama 25 sampai 40 menit tergantung respon masing-masing partisipan dalam menanggapi pertanyaan-pertanyaan yang sedang diajukan. Sebelum wawancara dimulai, data demografi dan penyakit pasien dikumpulkan dengan kuesioner terstruktur yang turut dilampirkan bersamaan dengan lembar informasi dan formulir persetujuan. Wawancara diadakan di ruang tunggu poliklinik/laboratorium/ instalasi farmasi rumah sakit, selain itu juga di rumah partisipan bila diperlukan informasi tambahan. Setelah sesi wawancara, partisipan diambil sampel darah untuk diperiksa kadar HbA1c, yang merupakan parameter kontrol glikemik dalam penelitian ini. Pengukuran kadar HbA1c dilakukan di laboratorium klinik Prodia dengan metode ion exchange high-performance liquid chromatography (HPLC) yang terstandarisasi oleh National Glycohemoglobin Standarization Program (NGSP) (Gambar 2).

\section{Kelaikan etik}

Persetujuan etik telah diperoleh dari Komisi Etik Penelitian Kedokteran dan Kesehatan Fakultas Kedokteran Universitas Gadjah Mada-RS Dr. Sardjito dengan nomor KE/ FK/576/EC/2015 sebelum penelitian dimulai.

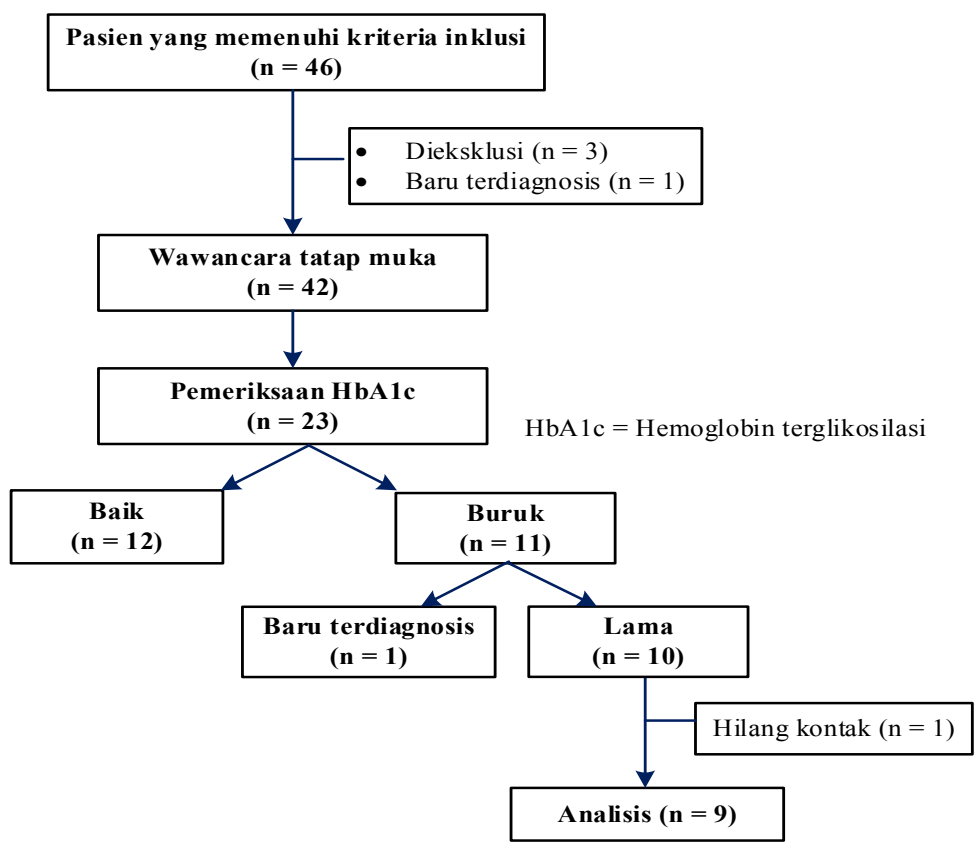

Gambar 2 Gambaran Umum Penelitian 
Formulir informed consent dalam Bahasa Indonesia telah ditandatangani oleh semua partisipan.

Analisis data/evaluasi

Seluruh hasil rekaman suara selama sesi wawancara ditranskrip verbatim ke Microsoft Word 2013 oleh tujuh orang asisten penelitian. Sebelum dilanjutkan untuk analisis, setiap transkrip dibaca kembali oleh peneliti utama untuk dilakukan identifikasi terhadap halhal yang masih memerlukan klarifikasi lebih lanjut atau informasi tambahan. Data mentah dikategorikan ke dalam matriks (Microsoft Excel 2013) yang berisi tema-tema yang ada di panduan wawancara, kemudian didiskusikan bersama dengan ahli yang kompeten (penulis keempat) untuk mengevaluasi temuan di lapangan. Masalah terkait dengan pengobatan berdasar atas Pharmaceutical Care Network Europe Version 6.2, systematic review mengenai faktor-faktor yang berkontribusi terhadap masalah-masalah terkait pengobatan ditinjau dari perspektif pasien DM, dan framework untuk meningkatkan kepatuhan pengobatan pasien ${ }^{21,28,31}$ digunakan sebagai acuan pengkategorian. Data yang diperoleh dari partisipan dengan kontrol glikemik baik dibandingkan dengan yang memiliki kontrol glikemik buruk untuk memastikan keabsahan data (trustworthiness). Pengambilan data lalu dilanjutkan sampai saturasi teoritis tercapai, yaitu ketika tidak diperoleh informasi baru pada saat wawancara berikutnya. ${ }^{32}$

\section{Hasil}

Terdapat total 23 partisipan yang berhasil diwawancara dan diketahui data mengenai kontrol glikemiknya. Sebanyak 11 dari 23 partisipan memiliki kontrol glikemik buruk $($ HbAlc $>7 \%)$. Salah satu di antaranya merupakan pasien baru didiagnosis sehingga hanya dapat diperoleh informasi mengenai faktor-faktor yang diduga menjadi pemicu munculnya penyakit. Karakteristik partisipan yang terperiksa kadar HbAlc-nya disajikan dalam Tabel 2.

Berdasarkan Tabel 2, DMT2 lebih banyak dialami oleh pasien perempuan, dan sebagian besar dialami pada orang berusia 50 tahun ke atas, tidak bekerja/pensiun, dan memiliki pendidikan tinggi. Seluruh partisipan tinggal dengan pasangannya (suami/istri). Dari 23 partisipan, terlihat bahwa rata-rata kontrol glukosa darah melebihi target pengendalian DM yang disepakati oleh para ahli (HbAlc $>7 \%$ ), meskipun demikian, sasaran terapi disesuaikan dengan kondisi klinis masingmasing pasien. Sebagian besar partisipan mendapatkan terapi antidiabetes oral (ADO) saja, baik tunggal maupun kombinasi. Durasi penyakit ke-23 partisipan rata-rata lebih dari 10 tahun. Median umur partisipan adalah 58 tahun dengan range 35-72 tahun.

Subtema atau kategori yang teridentifikasi sebagai pemicu masalah yang dialami pasien DMT2 dalam pengobatannya adalah faktor terkait dengan pasien (antara lain demografi, sosial, gaya hidup, dan hubungan dengan tenaga kesehatan), faktor terkait kondisi klinik (meliputi pemahaman tentang penyakit, efek penyakit, pengendalian penyakit, dan komorbiditas), faktor terkait obat (seperti pengetahuan tentang pengobatan, dan asupan obat). Rincian hasil identifikasi melalui wawancara dapat dilihat pada Gambar 3.

Faktor terkait pasien

Dari 9 partisipan yang dianalisis, semuanya merupakan penderita DM yang menahun (median durasi penyakit 10 tahun dengan range 1,5-30 tahun) dan memiliki kendali DM yang buruk (median $\mathrm{HbA} 1 \mathrm{c}$ 9,3\% dengan range $7,1-12,9 \%$ ), ditemukan terdapat 1 orang berusia di bawah 50 tahun yang menyatakan tidak patuh terhadap rejimen terapi karena mengalami reaksi obat yang tidak diinginkan.

“Actos [nama dagang obat DM oral] jarang 
Tabel 2 Karakteristik Demografi dan Klinis Partisipan $(\mathbf{n}=\mathbf{2 3})$

\begin{tabular}{|c|c|c|c|}
\hline Karakteristik & $\mathbf{n}$ & $\%$ & $\begin{array}{c}\text { Rata-Rata } \pm \text { SD } \\
\text { (Median; Minimum-Maksimum) }\end{array}$ \\
\hline $\begin{array}{l}\text { Jenis Kelamin } \\
\text { Perempuan }\end{array}$ & 12 & 52 & \\
\hline $\begin{array}{l}\text { Status Perkawinan } \\
\text { Menikah }\end{array}$ & 23 & 100 & \\
\hline $\begin{array}{l}\text { Usia* (tahun) } \\
<50 \\
\geq 50\end{array}$ & $\begin{array}{c}4 \\
19\end{array}$ & $\begin{array}{l}17 \\
83\end{array}$ & $57,5 \pm 10(58 ; 35-72)$ \\
\hline $\begin{array}{l}\text { Pendidikan Terakhir } \\
\text { SD } \\
\text { SMP-SMA } \\
\text { Diploma } \\
\text { Sarjana } \\
\text { Master }\end{array}$ & $\begin{array}{c}1 \\
10 \\
5 \\
6 \\
1\end{array}$ & $\begin{array}{c}4 \\
44 \\
22 \\
26 \\
4\end{array}$ & \\
\hline $\begin{array}{l}\text { Pekerjaan } \\
\text { Pensiun/tidak bekerja }\end{array}$ & 14 & 65 & \\
\hline $\begin{array}{l}\text { Durasi Penyakit* (tahun) } \\
<1 \\
1-5 \\
>5\end{array}$ & $\begin{array}{c}3 \\
5 \\
15\end{array}$ & $\begin{array}{l}13 \\
22 \\
65\end{array}$ & $10,7 \pm 10,4(8 ; 0-33)$ \\
\hline $\begin{array}{l}\text { Indeks Massa Tubuh* }\left(\mathbf{k g} / \mathbf{m}^{2}\right) \\
\text { Normal } \\
\text { Gemuk } \\
\text { Obese }\end{array}$ & $\begin{array}{c}6 \\
7 \\
10\end{array}$ & $\begin{array}{l}26 \\
30 \\
44\end{array}$ & $25,2 \pm 3,7(24,1 ; 18,9-33,2)$ \\
\hline $\begin{array}{l}\text { Jumlah ADO yang Diminum } \\
1 \text { ADO } \\
\text { Kombinasi } 2 \text { ADO } \\
\text { Kombinasi } 3 \text { ADO } \\
\text { Kombinasi } 4 \text { ADO }\end{array}$ & $\begin{array}{l}12 \\
4 \\
3 \\
2\end{array}$ & $\begin{array}{c}52 \\
17 \\
13 \\
9\end{array}$ & \\
\hline $\begin{array}{l}\text { Jumlah Item Obat yang Diminu } \\
1 \\
3 \\
4 \\
5 \\
6 \\
7 \\
8\end{array}$ & $\begin{array}{l}1 \\
8 \\
3 \\
4 \\
4 \\
2 \\
1\end{array}$ & $\begin{array}{c}4 \\
35 \\
13 \\
17 \\
17 \\
9 \\
4\end{array}$ & $4,5 \pm 1,7(4 ; 1-8)$ \\
\hline $\begin{array}{l}\text { Jumlah Insulin yang Digunakar } \\
1 \\
2\end{array}$ & $\begin{array}{c}11 \\
1\end{array}$ & $\begin{array}{c}92 \\
8\end{array}$ & \\
\hline $\begin{array}{l}\text { Pengobatan } \\
\text { Insulin dan ADO } \\
\text { Insulin saja } \\
\text { ADO saja }\end{array}$ & $\begin{array}{c}7 \\
5 \\
11\end{array}$ & $\begin{array}{l}30 \\
22 \\
48\end{array}$ & \\
\hline $\begin{array}{l}\text { HbA1c* }(\boldsymbol{\%}) \\
\text { Kontrol glikemik buruk }\end{array}$ & 11 & 48 & $7,9 \pm 2,0(6,9 ; 5,8-12,9)$ \\
\hline
\end{tabular}

Keterangan: $\mathrm{ADO}=$ Antidiabetes oral 


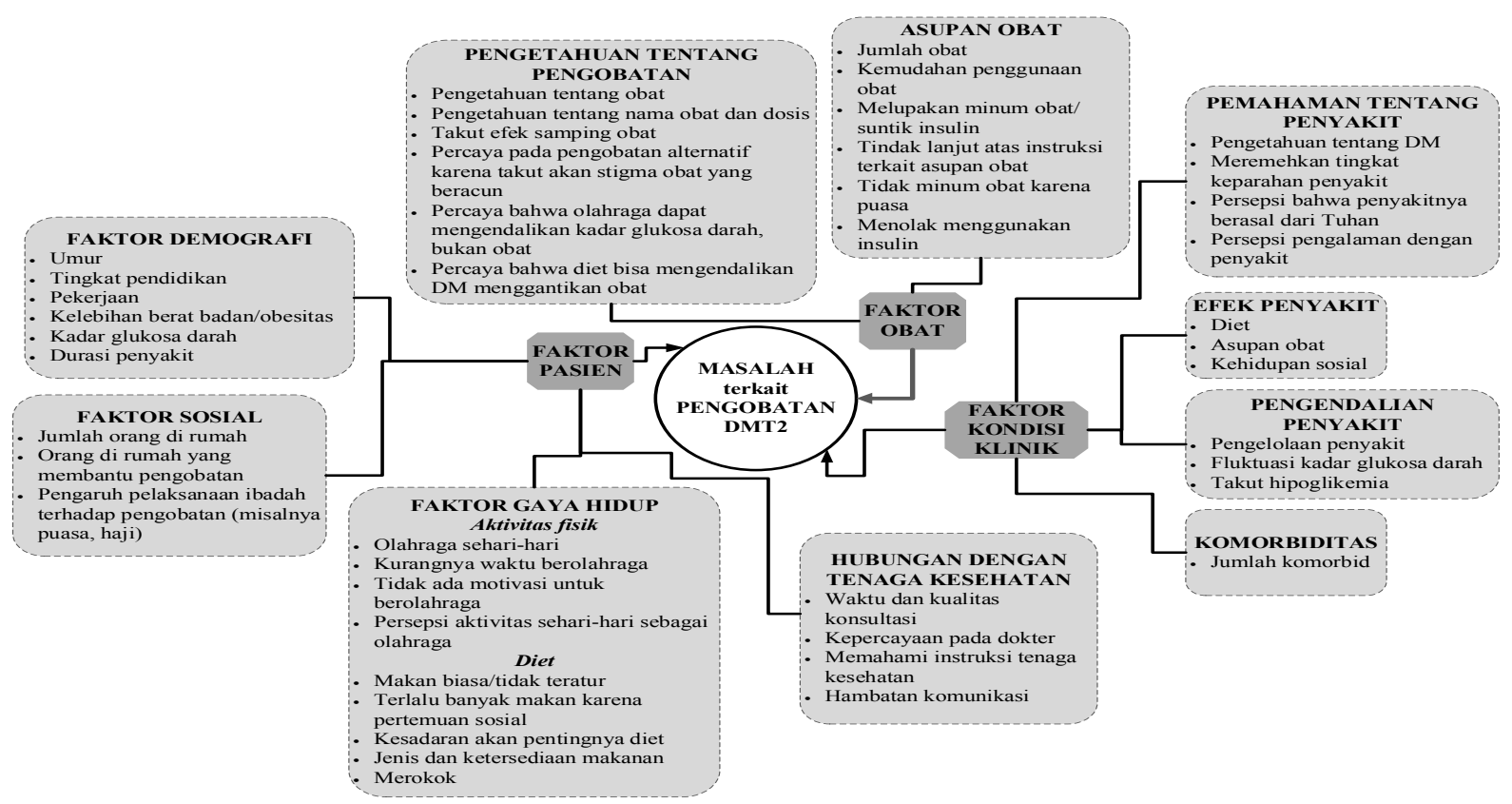

Gambar 3 Subtema yang Teridentifikasi dari Wawancara

(Dipresentasikan dalam poster di Pertemuan Ilmiah Tahunan Ikatan Apoteker Indonesia 2019)

saya minum. Soalnya kalau minum itu kakinya bengkak." (perempuan, 35 tahun, \#06)

Pada pasien dengan latar belakang pendidikan yang mempelajari makhluk hidup diperoleh jawaban lebih rinci mengenai pengetahuan tentang penyakitnya.

"Yang saya tahu, gangguan pada manajemen gula karena faktor insulin bisa atau reseptor insulin bisa dari seluruh jaringan, seluruh sel yang ada, seluruh sistem yang ada, seluruh kelenjar yang ada kalau sudah degenerasi kemudian sampai pada poin yang tersulit untuk menggantikannya seperti ini coba, kalau insulin saya itu sampai pada batas yang sangat rendah otomatis kan kita depend on insulin. Kalau sudah seperti itu, apa daya kita? Coba kalau memang ada metode yang bisa me-refresh sel-sel beta, semuanya kembali normal." (pendidikan sarjana biologi, laki-laki, 52 tahun, \#05)

Salah satu partisipan merupakan pensiunan dari Badan Kependudukan dan Keluarga Berencana Nasional (BKKBN), khususnya di sarana logistik, melaporkan bahwa ia banyak bergaul dengan tenaga kesehatan sehingga pengetahuan tentang obat diakuinya lebih baik. Hal itu menyebabkan persepsi penggunaan obat herbal tidak aman.

"Saya seperti herbal-herbal itu kan tidak uji klinik, saya takut. [kalau obat yang diberikan dokter?] Nah, itu saya tahu (teruji klinik). Soalnya saya sejak kecil (awal) memang (bekerja) di BKKBN di bagian logistiknya. Saya kan pimpinan di sarana di tingkat kabupaten. Jadi obatobatan harus melalui saya. Saya tahu sedikit-sedikit (tentang) obat. Teman dokter banyak. Di samping itu, istri saya bidan, jadi saya kalau mau beli obat ini baca-baca (rincian tentang produk obat) jadi saya ketakutan sendiri, lah." (laki-laki, 66 tahun, \#12)

Pernyataan selanjutnya mengimplikasikan bahwa pemahaman pasien mengenai kadar glukosa darah rendah dan tinggi sangat 
penting, agar dapat menginterpretasikan hasil pemeriksaan glukosa darah mandiri. Hal tersebut berguna dalam pengaturan diri terkait dengan jumlah dan jenis makanan, olahraga, maupun untuk mengetahui efektivitas obat atau insulin.

"Saya kalau (glukosa darah) puasa harusnya 100 kurang dikit, tapi (hasil pemeriksaan) 100 lebih sedikit. Berarti pola makan saya masih kebanyakan. Terus nanti (setelah makan) minum obat (diperiksa kadar glukosa darah 2 jam sesudah makan) harusnya 150 ke bawah, (hasil pemeriksaan) saya 132. Pernah saya tidak minum obat, saya kebetulan di pesta ada minuman makanan yang enakenak lah ya, ada es ada lain-lain manismanis semua. Terus sampai rumah cek, lho kok 218. Terus saya minum obat, turun cepat." (laki-laki, 66 tahun, \#12)

Faktor terkait kondisi klinik

Persepsi seseorang tentang penyakit DM tergantung pada pengalaman yang pernah dialami sendiri atau penderita lain. Pasien DM cenderung menganggap bahwa penyakitnya bukan merupakan penyakit yang parah karena tidak mengharuskan mereka terbaring sepanjang waktu selayaknya orang sakit.

"Penyakit ini termasuk ringan, ada yang lebih parah. Kalau ibu ini gula kering. Kalau gula basah itu misalnya ada luka kebacok atau kesandung, lama sembuh ndak bisa sembuh. Seperti temen saya itu sampe dipotong kakinya." (perempuan, pendidikan Sekolah Dasar, 62 tahun, \#43)

Pasien dengan durasi DM lebih lama cenderung telah dapat menerima kondisi penyakitnya. Berbeda dengan pasien yang baru terdiagnosis harus melalui tahap penyangkalan (denial), marah (anger), menawar (bargaining), dan depresi. “...saya berpikir yang namanya hidup mati itu Tuhan yang ngatur, tapi kalau kita bisa katakanlah mengikuti aturan main yang diciptakan Tuhan kenapa enggak? Termasuk kalau terpaksa harus minum obat, ngapain kita nggak minum obat? nggak minum obat nyatanya gulanya langsung naik. Ngapain kita enggak suntik insulin, pada saat kita depend on insulin, kalau enggak ada insulin ya kita klenger sendiri kan." (laki-laki, 52 tahun, \#05)

Kebiasaan yang terdapat dalam suatu masyarakat menjadikan pengalaman masa lalu sebagai acuan memahami karakteristik penyakit maupun menentukan sikap dan tindakan, termasuk implementasi pengaturan makan.

Manusia sebagai makhluk sosial tidak dapat lepas dari lingkungan. Dalam kehidupan bermasyarakat, sering terjadi hal-hal di luar harapan yang memicu terjadinya stres.

“... di samping itu pikiran. nah itu kuncinya, jadi makanya saya kemarin ngurus pemilu itu saya didaftar masuk KPPS. Dulu kan saya di tingkat kecamatan, PPPK. Terus panwas, tapi sekarang saya mundur soalnya saya tidak mau terlalu beban berat. Itu di antaranya, jadi pikiran harus santai, itu memengaruhi (gula darah)." (laki-laki, 66 tahun, \#12)

Faktor terkait obat

Pemahaman pasien mengenai mekanisme kerja obat yang sedang dikonsumsi berpengaruh pada perilaku patuh terhadap setiap rejimen terapi.

"Kalau acarbose eclid itu pada suapan pertama, dia harus segera bekerja mengendalikan substansi karbohidrat yang ada supaya nanti tidak segera pecah. Pelanpelan. Kemudian kalau metformin sehabis makan. Itu yang disarankan begitu. Kalau 
metformin tiga kali, tapi saya tergantung makan. Jadi kadang-kadang posisi sibuk nggak mungkin makan tiga kali ya sudah dua kali, ambil posisi itu, begitu." (lakilaki, 52 tahun, \#05)

Anggapan bahwa obat herbal bebas efek samping mendasari masyarakat yang masih menggunakan bahan alam untuk mengobati penyakit.

"Saya coba pake daun insulin, itu katanya bagus. Ya memang bagus, itu cuman apa ya? Lama-lama tu kok rasanya bosen gitu. Banyak kok yang nanem-nanem daun-daun itu buat obat." (perempuan, 62 tahun, \#43)

Pasien DMT2 dengan durasi penyakit lama telah membuktikan bahwa olahraga efektif menjaga kadar glukosa darah pada kisaran normal. Namun, terlalu sibuk dengan pekerjaan menjadikan pasien merasa tidak memiliki waktu dan kesempatan untuk berolahraga.

"Empat bulan terakhir saya off. Jalan itu tidak intens karena waktu tadi, biasanya kalau saya punya waktu, habis subuh biasanya saya (naik) sepeda 20 menit selesai, tapi akhir-akhir ini sudah tidak memungkinkan saya melakukan itu. Dan mungkin ini yang memperparah kondisi yang ada. Saya dulu waktu awal saya kombinasi dengan sepeda wuuiiih langsung turun (gula darah) ke sisi normal betul-betul normal. Rentang beberapa bulan sampai saya menghentikan (naik) sepeda. Itu bagus sebenernya. Gula yang ada pernah cukup rendah, 102 kalau ndak salah waktu puasa itu. Kemudian naik (gula 2 jam sesudah makan) itu 136 waktu itu. Itu nyaman sekali begitu nyaman sekali. Jadwal yang crowded sekali, kita akhirnya terdzolimi begitu." (laki-laki, 52 tahun, \#05)

Pasien dengan DM sering mengalami kesulitan dalam mengendalikan konsumsi makanan sehari-hari, seperti karbohidrat, lemak maupun protein, kecuali telah terindikasi mengalami kondisi klinis tertentu.

"Iya, saya diet. Tapi diet saya tidak terlalu ini (ketat), mengurangi saja. Jadi misalnya nasi tuh saya makan sedikit. Kemudian santan-santan tuh memang perut saya sudah tidak menerima gitu. Daging-daging juga sudah tidak (makan). Tahu, tempe saya tidak makan. Tahu, tempe, kacangkacangan hanya kalau pingin sekali ya nyoba aja. Karena kreatinnya tinggi jadi saya mengurangi." (perempuan, 66 tahun, \#11)

Salah satu perilaku yang sering dilakukan oleh pasien saat menggunakan obat adalah lupa, baik dilakukan secara sengaja maupun tidak.

"Pernah (lupa minum obat). Sering. Umpamanya pagi yang glimepiride itu kan setengah jam sebelum makan, itu kadang lebih dari setengah jam baru ingat makan. Katanya kalau insulin nggak boleh kaya gitu. Saya takutnya itu loh. Kadang-kadang belum minum obat tapi sudah makan." (perempuan, 54 tahun, \#32)

Kerjasama antara pasien dengan tenaga kesehatan dalam pengobatan DM diperlukan untuk mencapai keberhasilan terapi.

"Mengapa dok, saya makai insulin kok nggak bisa turun-turun dari 200 dok? nyuntiknya udah 3 kali. Ya itu dokter, hanya belum pas dengan dosisnya. Lha pasnya berapa? Tambahi, nambah 2, 2, 2 (unit). Dulu pernah hanya dikasih 1 hari 1 kali, kok tinggi dok? Pernah 2 kali, masih tinggi dok, akhirnya kembali 3 kali lagi, wah gimana ini (jadi) kelinci percobaan." (lakilaki, 57 tahun, \#02) 
Berkembang mitos yang menyebutkan bahwa tingkat keparahan penyakit DM ditandai oleh penggunaan insulin. Selain itu, kekhawatiran akan ketergantungan insulin juga membuat pasien enggan diterapi insulin.

\begin{abstract}
"Terus saya konsul ke dokter spesialis gula, sudah minum (obat) terus, suatu saat saya disuruh lebih baik pakai insulin. Saya tidak bisa menjawab, hanya saya menangis. Kenapa saya harus pakai insulin? Karena menurut saya kalau udah insulin tuh orang sudah parah, sudah mendekati kematian." (perempuan, 66 tahun, \#11)
\end{abstract}

\section{Pembahasan}

Wawancara pada penelitian berjenis kualitatif memberikan cerita-cerita yang unik tentang pengalaman hidup dengan diabetes secara personal. Terlepas dari keunikan tersebut, hasil yang diperoleh memberikan informasi mengenai aspek-aspek umum yang mendasari pengembangan model edukasi dan konseling yang efektif dan efisien untuk pasien DMT2. Hasil penelitian ini menunjukkan bahwa tidak tercapainya sasaran terapi disebabkan oleh banyak sekali faktor yang kompleks. Hambatan dan tantangan yang dialami pasien DM tidak hanya berasal dari aspek terapi farmakologi saja, ${ }^{9,24}$ akan tetapi juga terkait dengan aspek nonfarmakologi. ${ }^{33}$ Penelitian ini mejabarkan permasalahan kompleks yang berpotensi memperburuk kontrol glikemik, di antaranya adalah aktivitas spiritual, jenis dan intensitas olahraga, persepsi pada aktivitas sehari-hari sebagai olahraga, makan biasa/tidak teratur, terlalu banyak mengonsumsi makanan karena pertemuan sosial, kesadaran akan pentingnya diet, jenis dan ketersediaan makanan, merokok, persepsi bahwa penyakitnya berasal dari Tuhan, percaya pada pengobatan alternatif karena takut akan stigma obat yang beracun, percaya bahwa olahraga dan diet bisa mengendalikan kadar glukosa darah bukan obat, dan menolak menggunakan insulin.

Temuan-temuan pada penelitian ini dapat digunakan sebagai acuan penentuan target edukasi, yaitu pasien dengan usia yang lebih muda, karena berpotensi untuk mengalami masalah ketidakpatuhan disebabkan kurang menyadari sifat penyakitnya, sejalan dengan hasil studi oleh Ahmad dkk. ${ }^{34}$ Sesuai prediksi bahwa pasien yang berusia di atas 45 tahun lebih patuh dibandingkan yang lebih muda. ${ }^{35}$ Selain itu, sesuai dengan hasil studi Zou dkk. bahwa pasien dengan onset DM pada usia 31-45 tahun berisiko mengalami retinopati diabetik sebesar 1,815 kali lipat. ${ }^{36}$ Tingkat dan latar belakang pendidikan menjadi dasar penyampaian materi karena hal tesebut terkait dengan pemahaman pasien terhadap istilahistilah kesehatan. Pradono dan Sulistyowati dalam studinya menyatakan bahwa pendidikan tinggi mengajarkan orang untuk berpikir logis dan rasional dalam melihat isu dari berbagai perspektif sehingga dapat menganalisis dan memecahkan masalah. ${ }^{37}$ Penggunaan bahasa asli dan sederhana juga dapat meningkatkan pemahaman pasien. Referensi-referensi tentang edukasi yang terbaru juga perlu disampaikan kepada pasien yang bekerja, hal ini disebabkan mereka memiliki lebih banyak akses dengan materi edukasi. Temuan ini sesuai dengan hasil studi yang dilaporkan oleh Shrestha dkk. bahwa pekerjaan memiliki hubungan yang bermakna dengan pengetahuan, orang yang bekerja lebih terpelajar. ${ }^{38}$ Sebagian besar pasien DMT2 dengan kontrol glikemik buruk memiliki berat badan berlebih/obes, selaras dengan hasil studi Agrawal dkk. ${ }^{39}$ Maka dari itu, pasien-pasien tersebut perlu edukasi dan konseling mengenai perubahan kebiasaan makan, aktivitas fisik, serta stop konsumsi rokok untuk menunda terjadinya komplikasi. ${ }^{40}$ Kemampuan interpretasi hasil pemeriksaan darah perlu diajarkan pada penderita DMT2 sebagai upaya dalam pengaturan diri terkait dengan jumlah dan jenis makanan, olahraga, maupun untuk mengetahui efektivitas obat 
atau insulin. ${ }^{15}$ Pasien perlu selalu dimotivasi dengan mengingatkan kembali pilar-pilar pengelolaan DMT2, tidak memandang durasi penyakit agar kontrol glikemiknya terkendali. Hal ini didukung hasil studi Saleh dkk., makin lama durasi DM makin tinggi kadar HbA1c. ${ }^{41}$

Peran anggota keluarga dalam pengelolaan DM tidak hanya melalui pemberian dukungan dalam bentuk perhatian yang positif, seperti memuji pelaksanaan diet atau berolahraga bersama, namun juga perilaku yang tidak mendukung, yaitu seperti kritikan, omelan, paksaan. ${ }^{42}$ Semakin banyak anggota keluarga yang tinggal bersama, besar kemungkinan mendapatkan perhatian dalam hal aktivitas perawatan diri dan membantu pengobatan. Oleh sebab itu, anggota keluarga terdekat dapat juga menjadi target edukasi agar dapat berkolaborasi dalam menerapkan pola makan sehat, olahraga teratur, membantu pemantauan glukosa darah mandiri dan interpretasinya, mengelola stres, meminimalkan kemungkinan lupa menggunakan obat maupun lupa jadwal kontrol dokter. ${ }^{15}$ Pelaksanaan ritual ibadah (haji) berpotensi memengaruhi kepatuhan terhadap pengobatan pasien karena aktivitas fisik teratur, jumlah dan jenis makanan yang dikonsumsi terkontrol, kondisi psikis jauh dari stres menyebabkan pasien merasa tidak mengalami masalah dengan penyakitnya. ${ }^{43}$

Olahraga menjadi sebuah masalah karena sebagian besar pasien DMT2 beranggapan bahwa rutinitas harian termasuk olahraga. Di samping itu, terdapat keragu-raguan pasien dalam memilih olahraga yang sesuai dengan kondisi kesehatannya. Pasien cenderung menunjukkan sikap/perilaku makan yang membatasi dan menganggap bahwa kontrol diet yang kaku merupakan satu-satunya cara diet yang tepat. Tuntutan untuk mengikuti anjuran gizi menjadikan mereka lebih rentan tidak melaporkan jenis makanan yang dikonsumsi. Bertambahnya beban kerja tenaga kesehatan yang disebabkan jumlah pasien yang datang ke fasilitas kesehatan meningkat pesat dapat berdampak terhadap kualitas dan intensitas komunikasi efektif antara pasien dan tenaga kesehatan.

Temuan pasien DM cenderung menganggap bahwa penyakitnya bukan penyakit parah karena tidak mengharuskan mereka terbaring sepanjang waktu selayaknya orang sakit. Persepsi bahwa penyakit yang diidap berasal dari Tuhan muncul pada pasien dengan durasi DM lebih lama. Seperti dilaporkan Permana dan Harbiyan, pasien DM muslim Jawa di Yogyakarta berkeyakinan bahwa menjaga ketenangan pikiran yaitu dengan cara selalu mengingat Allah atau Tuhan dapat membantu mempertahankan glukosa darah. ${ }^{44}$ Pasien baru terdiagnosis berpotensi mengalami tahaptahap penyangkalan (denial), marah (anger), menawar (bargaining), dan depresi. ${ }^{45}$

Riwayat keluarga merupakan salah satu faktor risiko DM. ${ }^{46}$ Apabila ditemui pasien baru terdiagnosis, belum tentu mereka minim akan pengalaman yang berhubungan dengan penyakit DM karena kebiasaan masyarakat menjadikan pengalaman masa lalu sebagai acuan dalam memahami suatu keadaan serta untuk menentukan sikap maupun tindakan. Kebiasaan untuk mengamati kondisi-kondisi tertentu terkait dengan penyakit digunakan penderita dalam pengelolaan diri sendiri. Kurangnya pemahaman mengenai hubungan antara diet dengan penyakit menjadi sebuah hambatan kepatuhan terhadap pengaturan makan. Penderita DM seringkali mengalami kesulitan dalam mengendalikan konsumsi karbohidrat, lemak, dan protein kecuali sudah terindikasi mengalami kondisi klinis tertentu. Pasien DMT2 dengan durasi penyakit lama telah membuktikan bahwa olahraga teratur efektif menjaga kadar glukosa darah pada rentang normal. Namun demikian, kesibukan yang menyita waktu juga menjadi hambatan. Selain itu, tantangan yang dialami pasien DM adalah mengelola kondisi psikologis. Hal ini konsisten dengan hasil studi yang dilaporkan Helgeson dkk. bahwa penderita DM yang 
bekerja dan memiliki pendapatan yang lebih banyak lebih besar kemungkinan mengalami stres. ${ }^{47}$ Dalam kehidupan bermasyarakat, sering terjadi hal-hal yang memicu stres.

Ketidakpahaman akan dampak penurunan fungsi pankreas yang menyebabkan sekresi insulin berkurang, yang lalu memperparah kondisi resistensi insulin, menjadikan pasien pengidap DM tidak memahami tujuan dari pengobatan. Berkembangnya mitos bahwa tingkat keparahan penyakit ditandai dengan penggunaan insulin memicu pengidap DM menjadi malu ketika menggunakan insulin. Selain itu, kekhawatiran insulin menyebabkan ketergantungan juga mengakibatkan mereka enggan diterapi insulin.

Terdapat beberapa keterbatasan penelitian terkait dengan pengumpulan data. Pertama, sub-sub tema yang terbangun hanya terasa dari perspektif pasien DMT2 saja. Triangulasi dengan observasi aktivitas pengelolaan diri pasien DMT2, wawancara mendalam dengan tenaga kesehatan, maupun diskusi kelompok terfokus perlu dilakukan untuk membangun justifikasi tema-tema secara koheren, dengan demikian hasil penelitian dapat menjadi lebih valid. ${ }^{48}$ Kedua, masalah-masalah yang dialami oleh pasien DMT2 yang teridentifikasi pada penelitian ini tidak dapat digeneralisasikan pada kelompok demografi yang berbeda dari populasi penelitian ini. Ketiga, dalam proses pengumpulan data ditemui partisipan yang tidak memahami maksud pertanyaan dalam Bahasa Indonesia. Oleh sebab itu, kuesioner versi Bahasa Jawa mungkin dapat divalidasi sebagai alat ukur. Kemungkinan lain adalah mengeksklusi partisipan yang tidak mahir berbahasa Indonesia.

\section{Simpulan}

Penelitian menyimpulkan bahwa penderita dengan durasi DM kurang dari lima tahun memeriksa kadar glukosa darah hanya pada saat akan kontrol dokter. Kondisi psikologis yang buruk dapat memicu peningkatan kadar glukosa darah. Pasien DMT2 memerlukan edukasi tentang komplikasi DM, efek samping obat, penggunaan obat herbal atau suplemen, serta klarifikasi tentang mitos penggunaan insulin.

\section{Ucapan Terima Kasih}

Ungkapan terima kasih disampaikan kepada para pasien penelitian, rekan sejawat apoteker, dokter, serta perawat di rumah sakit tempat penelitian.

\section{Pendanaan}

Penelitian ini merupakan sebagian dari hasil penelitian disertasi yang didanai oleh Kementerian Riset Teknologi dan Pendidikan Tinggi Republik Indonesia melalui Beasiswa Unggulan Dalam Negeri (BUDN). Poster dipresentasikan dalam Pertemuan Ilmiah Tahunan (PIT) Ikatan Apoteker Indonesia (IAI) 2019 di Bandung, 13-15 Maret 2019.

\section{Konflik Kepentingan}

Seluruh penulis menyatakan tidak terdapat potensi konflik kepentingan dengan penelitian, kepenulisan (authorship), dan atau publikasi artikel ini.

\section{Daftar Pustaka}

1. Anna LK. Pengobatan diabetes habiskan 33 persen biaya kesehatan dari BPJS. Harian Kompas. [diunduh 09 September 2016]. Tersedia dari: http://lifestyle.kompas.com/ $\mathrm{read} / 2016 / 04 / 09 / 150000023 /$ Pengobatan. Diabetes.Habiskan.33.Persen.Biaya.Kes ehatan.dari.BPJS

2. Ali N. Diabetes and you: A comprehensive, holistic approach. United Kingdom: Rowman \& Littlefield Publisher, Inc.; 2011.

3. Rudianto A, Lindarto D, Decroli E, 
Shahab A, Tarigan TJE, Adhiarta I, et al. Konsensus pengendalian dan pencegahan diabetes melitus tipe 2 di Indonesia 2011. Perkumpulan Endokrinologi Indonesia; 2011.

4. Aghili R, Polonsky WH, Valojerdi AE, Malek M, Keshtkar AA, Esteghamati A, et al. Type 2 diabetes: Model of factors associated with glycemic control. Can J Diabetes. 2016;40(5):424-30. doi: 10.10 16/j.jcjd.2016.02.014

5. Khattab M, Khader YS, Al-Khawaldeh A, Ajlouni K. Factors associated with poor glycemic control among patients with type 2 diabetes. J Diabetes Complications. 2010;24(2):84-9. doi: 10.1016/j.jdiacom p. 2008

6. Olson EA, McAuley E. Impact of a brief intervention on self-regulation, selfefficacy and physical activity in older adults with type 2 diabetes. J Behav Med. 2015;38(6):886-98. doi: 10.1007/s10865 -015-9660-3

7. Dalal MR, Grabner M, Bonine N, Stephenson JJ, DiGenio A, Bieszk N. Are patients on basal insulin attaining glycemic targets? Characteristics and goal achievement of patients with type 2 diabetes mellitus treated with basal insulin and physician-perceived barriers to achieving glycemic targets. Diabetes Res Clin Pract. 2016;121:17-26. doi: 10. 1016/j.diabres.2016.08.004

8. Shareef J, Fernandes J, Samaga L. Clinical pharmacist interventions in drug therapy in patients with diabetes mellitus and hypertension in a university teaching hospital. Int J Pharm Sci Res. 2015;6 (10): 4424-32. doi: 10.13040/IJPSR.0975-823 2.6(10).4424-32.

9. Huri HZ, Wee HF. Drug related problems in type 2 diabetes patients with hypertension: A cross-sectional retrospective study. BMC Endocr Disord. 2013;13(1):2. doi: 10.1186/1472-6823-1
3-2

10. Lenander C, Elfsson B, Danielsson B, Midlöv P, Hasselström J. Effects of a pharmacist-led structured medication review in primary care on drug-related problems and hospital admission rates: A randomized controlled trial. Scand J Prim Health Care. 2014;32(4):180-6. doi: 10.3 109/02813432.2014.972062

11. Shareef J, Fernandes J, Samaga L. Assessment of clinical pharmacist interventions in drug therapy in patients with diabetes mellitus in a tertiary care teaching hospital. Diabetes Metab Syndr Clin Res Rev. 2016;10(2):82-7. doi: 10.1 016/j.dsx.2015.09.017.

12. Al-Qazaz HK, Hassali MA, Shafie AA, Syed Sulaiman SA, Sundram S. Perception and knowledge of patients with type 2 diabetes in Malaysia about their disease and medication: A qualitative study. Res Soc Adm Pharm. 2011;7(2):180-91. doi: 10.1016/j.sapharm.2010.04.005.

13. World Health Organization. Global report on diabetes. Geneva, Switzerland: World Health Organization; 2016.

14. Sasongko MB, Widyaputri F, Agni AN, Wardhana FS, Kotha S, Gupta P, et al. Prevalence of diabetic retinopathy and blindness in Indonesian adults with type 2 diabetes. Am J Ophthalmol. 2017;181:7987. doi: 10.1016/j.ajo.2017.06.019.

15. Wahyuningrum R. Modul konseling saran apoteker pada pasien (SAPA) diabetes melitus tipe 2 untuk meningkatkan pengetahuan, perilaku, kepatuhan pengobatan, dan luaran klinik (disertasi). Yogyakarta: Universitas Gadjah Mada; 2018.

16. Gillani SW, Sulaiman SAS, Abdul MIM, Saad SY. A qualitative study to explore the perception and behavior of patients towards diabetes management with physical disability. Diabetol Metab Syndr. 2017;9(1):58. doi: 10.1186/s13098-017- 
0257-6

17. O'Brien BC, Harris IB, Beckman TJ, Reed DA, Cook DA. Standards for reporting qualitative research: A synthesis of recommendations. Acad Med. 2014;89 (9):1245-51. doi: 10.1097/ACM.000000 0000000388

18. Badan Penelitian dan Pengembangan Kesehatan Kementerian Kesehatan Republik Indonesia. Riset kesehatan dasar (Riskesdas) 2013. Jakarta: Kementerian Kesehatan Republik Indonesia; 2013.

19. Informasi kependudukan D.I. Yogyakarta. Jumlah penduduk menurut jenis kelamin semester I 2015 [diunduh 04 Maret 2015]. Tersedia dari: https://kependudukan. jogjaprov.go.id/olah.php?module=statisti $\mathrm{k} \&$ periode $=3 \&$ jenisdata $=$ penduduk $\&$ ber dasarkan $=$ jumlahpenduduk $\&$ prop $=34 \& \mathrm{k}$ $\mathrm{ab}=00 \& \mathrm{kec}=00$ )

20. Palinkas LA, Horwitz SM, Green CA, Wisdom JP, Duan N, Hoagwood K. Purposeful sampling for qualitative data collection and analysis in mixed method implementation research. Adm Policy Ment Health. 2015;42(5):533-44. doi: 10. 1007/s10488-013-0528-y

21. Al Hamid A, Ghaleb M, Aljadhey H, Aslanpour Z. A systematic review of qualitative research on the contributory factors leading to medicine-related problems from the perspectives of adult patients with cardiovascular diseases and diabetes mellitus. BMJ Open. 2014;4(9): e005992. doi: 10.1136/bmjopen-2014-00 992

22. Alldredge BK, Corelli RL, Ernst ME, Guglielmo BJ, Jacobson P, Kradjan WA, et al. Koda-Kimble and Young's applied therapeutics: The clinical use of drugs, 10th Edition. Philadelphia: Lippincott Williams \& Wilkins; 2012.

23. Claydon-Platt K, Manias E, Dunning T. Medication-related problems occurring in people with diabetes during an admission to an adult teaching hospital: A retrospective cohort study. Diabetes Res Clin Pract. 2012;97(2):223-30. doi: 10.1 016/j.diabres.2012.03.003

24. Huri HZ, Ling LC. Drug-related problems in type 2 diabetes mellitus patients with dyslipidemia. BMC Public Health. 2013; 13(1):1192. doi: 10.1186/1471-2458-131192

25. Hussein Z, Taher SW, Gilcharan Singh HK, Chee Siew Swee W. Diabetes care in Malaysia: Problems, new models, and solutions. Ann Glob Health. 2015;81(6): 851-62. doi: 10.1016/j.aogh.2015.12.016

26. Kueh YC, Morris T, Borkoles E, Shee $\mathrm{H}$. Modelling of diabetes knowledge, attitudes, self-management, and quality of life: A cross-sectional study with an Australian sample. Health Qual Life Outcomes. 2015;13(1):129. doi: 10.1186/ s12955-015-0303-8

27. Ogunbayo OJ, Schafheutle EI, Cutts C, Noyce PR. A qualitative study exploring community pharmacists' awareness of, and contribution to, self-care support in the management of long-term conditions in the United Kingdom. Res Soc Adm Pharm. 2015;11(6):859-79. doi: 10.1016/ j.sapharm.2014.12.010

28. Pharmaceutical Care Network Europe. Classification for drug related problems V6.2. Pharmaceutical Care Network Europe Foundation; 2010.

29. Roozendaal BW, Krass I. Development of an evidence-based checklist for the detection of drug related problems in type 2 diabetes. Pharm World Sci. 2009; 31(5):580-95. doi: 10.1007/s11096-0099312-1

30. Truong T, Britton M, Harrison D, Letassy $\mathrm{N}$, Armor B, Tonemah D, et al. Assessing the need for diabetes self-management education in the Oklahoma city vietnamese community. Diabetes Ther. 2011;2(2):8191. doi: 10.1007/s13300-010-0020-6 
31. Wiener ES, Mullins CD, Pincus KJ. A framework for pharmacist-assisted medication adherence in hard-to-reach patients. Res Soc Adm Pharm. 2015;11 (5):595-601. doi: 10.1016/j.sapharm.201 4.11.010

32. Fusch PI, Ness LR. Are we there yet? Data saturation in qualitative research. Qual Rep. 2015;20(9):1408-16.

33. Al Hamid AM, Ghaleb M, Aljadhey H, Aslanpour Z. Factors contributing to medicine-related problems in adult patients with diabetes and/or cardiovascular diseases in Saudi Arabia: A qualitative study. BMJ Open. 2017;7(11):e017664. doi: 10.1136/bmjopen-2017-017664

34. Ahmad NS, Islahudin F, Paraidathathu T. Factors associated with good glycemic control among patients with type 2 diabetes mellitus. J Diabetes Investig. 2014;5(5):563-9. doi: 10.1111/jdi.12175

35. D'Antoni D, Smith L, Auyeung V, Weinman J. Psychosocial and demographic predictors of adherence and non-adherence to health advice accompanying air quality warning systems: A systematic review. Environ Health. 2017;16(1):100. doi: 10. 1186/s12940-017-0307-4

36. Zou W, Ni L, Lu Q, Zou C, Zhao M, Xu $X$, et al. Diabetes onset at 31-45 years of age is associated with an increased risk of diabetic retinopathy in type 2 diabetes. Sci Rep. 2016;6(1):38113. doi: 10.1038/ srep38113

37. Pradono J, Sulistyowati N. (Correlation between education level, knowledge of environmental health, healthy behavior with health status) correlation study on people aged 10-24 in Jakarta Pusat. Bul Penelit Sist Kesehat. 2014;17(1):89-95. doi: 10.22435/bpsk.v17i1Jan.3579

38. Shrestha N, Yadav SB, Joshi AM, Patel BDP, Shrestha J, Bharkher DL. Diabetes knowledge and associated factors among diabetes patients in central Nepal. Int J
Collab Res Intern Med Public Health. 2015;7(5):82-91.

39. Agrawal N, Agrawal MK, Kumari T, Kumar S. Correlation between body mass index and blood glucose levels in jharkhand population. Int $\mathrm{J}$ Contemp Med Res. 2017;4(8):1633-6.

40. American Diabetes Association. Obesity management for the treatment of type 2 diabetes. In: Diabetes Care. American Diabetes Association; 2016.

41. Saleh F, Ara F, Afnan F. Assessment of gap between knowledge and practices among type 2 diabetes mellitus patients at a tertiary-care hospital in Bangladesh. Adv Public Health. 2016;2016:1-7. doi: $10.1155 / 2016 / 4928981$

42. Mayberry LS, Osborn CY. Family support, medication adherence, and glycemic control among adults with type 2 diabetes. Diabetes Care. 2012;35(6):1239-45. doi: $10.2337 / \mathrm{dc} 11-2103$

43. Wahyuningrum R, Wahyono D, Mustofa M, Prabandari YS. A qualitative study discovering the common medicationtherapy problems in patients with type 2 diabetes mellitus (T2DM) in Asian $\mathrm{J}$ Pharm Clin Res. 2017;10(7):246. doi: 10. 22159/ajpcr.2017.v10i7.18217

44. Permana I, Harbiyan MT. How Javanese muslim with diabetes in Yogyakarta managing the daily self-care activity. Int $\mathbf{J}$ Public Health Sci. 2015;4(4):241-9. doi: 10.13140/RG.2.1.1766.2960

45. Kalra S, Jena B, Yeravdekar R. Emotional and psychological needs of people with diabetes. Indian J Endocrinol Metab. 2018;22(5):696-704. doi: 10.4103/ijem.I JEM_579_17

46. Zhao Y, Song C, Ma X, Ma X, Wang Q, Ji $\mathrm{H}$, et al. Synergistic effect of family history of diabetes and dietary habits on the risk of type 2 diabetes in Central China. Int J Endocrinol. 2017;2017:9707284. doi: 10. $1155 / 2017 / 9707284$ 
47. Helgeson VS, Van Vleet M, Zajdel M. Diabetes stress and health: Is aging a strength or a vulnerability? J Behav Med. 2019(Nov):31728816. doi: 10.1007/s108 65-019-00106-4
48. Creswell JW. Research design: Qualitative, quantitative, and mixed methods approaches, $3^{\text {rd }}$ Edition. Thousand Oaks California: Sage Publications; 2009. 